\title{
PERAN PENDIDIKAN ILMU PENGETAHUN SOSIALDALAM MEMBENTUK KARAKTER PLURALIS SISWA DI MTs N 11 CIREBON
}

\author{
Lani Rofiqoh $^{1}$, Aris Suherman ${ }^{2}$ \\ IAIN Syekh Nurjati Cirebon ${ }^{1,2}$ \\ lanyrofiqoh@gmail.com;indrinurindie@ymail.com
}

\begin{abstract}
Abstrak
Penelitian ini bertujuan untuk memperoleh data tentang proses pembelajaran pendidikan IPS, karakter pluralis siswa dengan adanya pendidikan IPS, dan Faktor yang mendukung dan menghambat dalam membentuk karakter pluralis siswa di MTs N 11 Cirebon. Sebagai kerangka pemikir, Peran Pendidikan IPS merupakan pengupayaan pembentukan karakter pluralis siswa dalam dunia pendidikan sehingga menghasilkan keberhasilan dalam belajar dan mempunyai rasa toleransi atau, saling menghargai, saling percaya, dan gotong royong. Penelitian menggunakan metode kualitatif deskriptif dan menggunakan teknik pengumpulan data dalam penelitian ini menggunakan observasi patsisipatif, wawancara mendalam, dokumentasi dan triangulai.Data yang diperlukan dalam penelitian ini berupa data teoritik dan data empirik, sumber data teoritik diambil dari referensi buku-buku dan referensi lain yang sesuai dengan kajian penelitian. Data empirik diambil dari hasil kegiatan observasi, wawancara, dokumentasi, dan triangulasi yang dilakukan peneliti. Teknik analisis data melalui tiga tahap yaitu reduksi data, penyajian data, dan verifikasi data. Hasil Penelitian menunjukan bahwa 1) proses pembelajaran pendidikan IPS di MTs N 11 Cirebon sudah maksimal, terbukti dengan proses perencanaa, pelaksanaa, dan tindak lanjut yang baik dilakukakn oleh guru mata pelajaran IPS kepada siswasiswinya. 2) karakter pluralis siswa sudah mulai ditanamkan melalui proses pendidikan IPS Fakta-fakta yang menjadi upaya penanaman nilai pluralis pada siswa yaitu menghargai pendapat orang lain, toleransi, kebebasan yang bertanggung jawab. Sehingga mampu menghasilkan siswa yang kreatif, inovatif, berguna bagi nusa dan bangsa, memiliki masa depan yang cerah dan mendapatkan kehidupan yang lebih baik.
\end{abstract}

\section{Kata Kunci: Peran Pendidikan IPS, Karakter Pluralis}

\begin{abstract}
This study aims to obtain the data about the learning process of social studies, pluralist character of students with the education of social studies, and the factors that support and inhibit in shaping the pluralist character of students in MTs $N 11$ Cirebon. As a framework of thinkers, social studies is a striving for the formation of pluralist character of students in the world of education so as to produce success in learning and have a sense of tolerance or mutual respect, mutual trust, and mutual cooperation. The research used descriptive
\end{abstract}


qualitative method and using data collection technique, in this research using observation of patsisipatif, in-depth interview, documentation and triangulation. The data needed in this study are theoretical data and empirical data, the theoretical data source is taken from the reference books and other references in accordance with the study research. Empirical data is taken from observation, interview, documentation, and triangulation conducted by researcher. Data analysis technique through three stages of data reduction, data presentation, and data verification. The result of the research shows that 1) the learning process of social studies in MTs $N 11$ Cirebon has been maximal, as evidenced by the process of planning, execution, and good follow-up done by social studies teachers to the students. 2) the pluralist character of the students has begun to be invested through the social studies process. Facts that become the effort of plural value placement in the students that respect the opinion of others, tolerance, freedom of responsibility. So as to produce students who are creative, innovative, useful for the nation, have a bright future and get a better life.

\section{Keywords: Social Studies Role, Pluralist Character}

\section{A. Pendahuluan}

1. Latar Belakang Masalah

Di era yang semakin maju dan berkembang, saat manusia bukan hanya bersaing dengan manusia tetapi sudah mulai bersaing dengan teknologi, pada saat itu pula sumber daya manusia mengalami penurunan. Manusia seolah dimanjakan dengan adanya teknologi yang semakin canggih, hal inilah yang membuat mereka menjadi malas dan mengakibatkan lemahnya sumber daya alam yang dimiliki. Tetapi dengan adanya pendidikan, hal tersebut masih bisa diatasi.

Undang-Undang Nomor 20 tahun 2003 tentang Sistem Pendidikan Nasional pasal 3 menjelaskan "fungsi pendidikan nasional adalah mengembangkan kemampuan dan membentuk watak serta peradaban bangsa yang bermartabat dalam rangka mencerdaskan kehidupan bangsa; dan tujuan pendidikan nasional untuk mengembangkan potensi peserta didik agar menjadi manusia yang beriman dan bertakwa kapada Tuhan Yang Maha Esa, berakhlak mulia, sehat, berilmu, cakap, kreatif, mandiri, dan menjadi warga Negara yang demokratis serta bertanggung jawab.” (http://referensi.elsam.or.id/2014/11/uunomor-20-tahun-2003-tentang sistem-pendidikan-nasional/ diakses pada tanggal 02 Januari 2018 pukul 10.20 WIB). 
Pendidikan IPS adalah suatu penyederhanaan disiplin ilmu-ilmu sosial, ideologi negara dan disiplin ilmu lainnya serta masalah-masalah sosial yang terkait, yang diorganisasikan dan disajikan secara ilmiah dan psikologis untuk tujuan pendidikan pada tingkat pendidikan dasar dan menengah (Soemantri, 1998:8).

Sikap pluralis anak menurut teori struktur dan pembentukan sikap menurut Azwar (1997: 30-32) adalah "pengalaman pribadi, kebudayaan, orang lain yang dianggap penting, media massa, institusi atau lembaga pendidikan atau lembaga agama, serta faktor emosi dalam diri individu.”

Pembelajaran IPS (Ilmu Pengetahuan Sosial) merupakan pengetahuan mengenai sesuatu yang berhubungan dengan masyarakat yang didalamnya terdapat disiplin ilmu sosial seperti sejarah, geografi, ekonomi, dan antropologi yang mempelajari masalah-masalah sosial. Dalam mata pelajaran IPS kelas VIII terdapat materi yang membahas tentang "Multikulturalisme, Pluralisme, dan Demokratisme" tujuan dari pembelajaran tersebut siswa-siswi diharapkan dapat menanamkan nilai-nilai sosial serta saling menghargai, toleransi, saling percaya, dan saling membutuhkan. Berdasarkan penelitian awal saat observasi di MTs N 11 Cirebon ditemukan bahwa, proses pembelajaran mata pelajaran IPS yang belum maksimal, terlihat bahwa guru hanya menyampaikan meteri dengan metode ceramah saja, hal ini menyebabkakn siswa-siswi jenuh dan mengantuk saat belajar, kemudian siswa-siswi cenderung belum dapat menerima hal-hal yang berbeda dengan dirinya dan mudah terprovokasi oleh teman lain yang lebih popular di kalangan mereka. Karena di MTs N 11 Cirebon ini ada dua suku bahasa yang sangat mendominasi di sekolah tersebut yakni siswa-siswi yang berbahasa Sunda dan Jawa. Siswa-siswi dari suku bahasa Sunda seringkali mengejek dan menghina suku Jawa, dan begitu sebaliknya. Letak geografis sekolah nya pun berbatasan dengan daerah yang berbahasa Jawa dan daerah yang berbahasa Sunda. Pada siswa perempuan cenderung sudah membentuk geng-geng atau berkelompok- kelompok, dan antar kelompok terkadang masih sulit saling menerima perbedaan yang ada. Peran pendidikan IPS belum mengarahkan dan membentuk karakter siswa yang menanamkan nilai-nilai sosial. Dengan demikian peran pendidikan IPS merupakan solusi untuk 
mengarahkan dan membangun sikap siswa yang saling menghargai, toleransi, gotong-royong, tanggung jawab dalam berinteraksi secara efektif dengan lingkungan sosial dan alam dalam jangkauan pergaulan serta keberadaannya, sehingga menghasilkan sikap pluralis siswa. Karena sikap pluralis merupakan sikap mengakui, menghargai, dan toleransi adanya keberagaman atau kemajemukan. Sedangkan pembelajaran pendidikan IPS ialah pembelajaran yang menekankan peran aktif siswa dalam membangun pemahaman dan memberikan makna terhadap informasi dan peristiwa yang dialami.

Berdasarkan latar belakang masalah di atas maka penulis menganngap penting Peran Ilmu Pengetahuan Sosial dalam upaya pembentukan karakter

pluralis siswa atas dasar fokus masalah tersebut penulis menganggkat sebuah judul penelitian dengan judul "Peran Pendidikan Ilmu Pengetahuan Sosial dalam Membentuk Karakter Pluralis Siswa di MTs N 11 Cirebon.”

2. Rumusan Masalah

Berdasarkan fokus kajian di atas, maka rumusan masalah pada penelitian ini adalah sebagai berikut:

a. Bagaimana proses pembelajaran pendidikan IPS di MTsN 11 Cirebon ?

b. Bagaimana karakter pluralis siswa dengan adanya pendidikan IPS di MTs N 11 Cirebon?

c. Faktor apa saja yang menghambat dan mendukung dalam pembentukan karakter pluralis siswa di MTs N 11 Cirebon?

3. Tujuan Penelitian

Berdasarkan rumusan masalah diatas maka tujuan penelitian ini adalah sebagai berikut :

a. Mendeskripsikan proses pembejaran pendidikan Ilmu Pengetahuan Sosial di MTs N 11 Cirebon.

b. Megetahui karakter pluralis siswa dengan adanya pendidikan IPS di MTs N 11 Cirebon.

c. Mengetahui faktor apa saja yang menghambat dan mendukung dalam pembentukan karakter pluralis siswa di MTs N 11 Cirebon. 


\section{B. KAJIAN TEORI}

1. Pengertian Pendidikan Ilmu Pengetahuan Sosial (IPS)

Rumusan tentang pengertian IPS telah banyak dikemukakan oleh para ahli IPS atau Social Studies. IPS dapat diartikan dengan "penelaahan atau kajian tentang masyarakat”. Dalam mengkaji masyarakat, guru dapat melakukan kajian dari berbagai perspektif sosial, seperti kajian melalui pengajaran sejarah, geografi, ekonomi, sosiologi, antropologi politik- pemerintahan, dan aspek psikologi sosial yang disederhanakan untuk mencapai tujuan pembelajaran(Nadir dkk, 2009: 9).

IPS merupakan pewujudan dari suatu perdekatan interdisipliner dari ilmu sosial. Ia merupakan integrasi dari berbagai cabang ilmu sosial yakni sosiologi, antropologi, budaya, psikologi, sejarah, geografi, ekonomi, ilmu politik dan ekologi manusia, yang diformulasikan untuk untuk tujuan intruksional dengan materi dan tujuan yang disederhanakan agar mudah dipelajari (Moeljono, 1980:8).

\section{Pengertian Karakter}

Kata karakter berasal dari kata Yunani charassein, yang berarti mengukir sehingga terbentuk pola. Artinya mempunyai karakter yang baik adalah tidak secara otomatis dimiliki oleh setiap manusia begitu ia dilahirkan, tetapi memerlukan proses panjang melalui pengasuhan dan pendidikan (proses”pengukiran”). Dalam istilah bahasa Arab karakter ini mirip dengan akhlak (akar kata khuluk), yaitu menggambarkan bahwa akhlak adalah tingkah laku seseorang yang berasa dari hati yang baik (Megawangi, 2004:25).

3. Pendidikan Karakter

Pendidikan karakter menurut Zubaedi (2011:14-15) menyatakan bahwa "Character education is the deliberate effort to cultivate virtue that is objectively good human qualities that are good for the individual person and good for the whole society." Yang artinya yakni "Pendidikan karakter adalah usaha sadar untuk mewujudkan kebajikan, yaitu kualitas kemanusiaan yang baik secara objektif, bukan hanya baik untuk individu perseorangan, tetapi juga baik untuk masyarakat secara keseluruhan”. 
Pendidikan Karakter dalam setting sekolah memiliki tujuan. Tujuan pendidikan karakter adalah memfasilitasi penguatan dan pengembangan nilainilai tertentu sehingga terwujud dalam perilaku anak, baik ketika proses sekolah maupun setelah proses sekolah / setelah lulus dari sekolah Menurut (Kesuma, 2012:9).

\section{Pengertian Pluralis}

Pluralitas adalah kemajemukan yang didasari oleh keutamaan (keunikan) dan kekhasan, konsep pluralitas mengandaikan adanya hal-hal yang lebih dari satu keragaman menunjukkan bahwa keberadaan yang lebih dari satu itu berbedabeda, heterogen, dan bahkan tak dapat disamakan. Sejalan dengan konsep pluralitas muncul pula konsep pluralisme yang isinya hampir sama membahas tentang kemajemukan dan keragaman. Kemajemukan (pluralitas) adalah sebuah keniscayaan yang tak dapat dinafikan. Itu memang benar. Ada kaum pria dan wanita, tua dan muda, yang berkulit hitam dan putih, dengan beragam agama dan kepercayaan. Menarik garis lurus, bahwa kemajemukan itu identik dengan pluralisme, tentu merupakan kesalahan, kalau tidak mau dianggap penyesatan (Kuntowijoyo, 2017:333-334).

Baydhawy (2007:77-95) mendeskripsikan beberapa karakter yang mencerminkan sikap pluralis: “(1) Hidup dalam Perbedaan (Sikap Toleransi/Tasamuh), (2) Sikap Saling Menghargai, (3) Saling Percaya (Husnudzan), (4) Interdependen (sikap saling membutuhkan/saling ketergantungan), (5) Apresiasi terhadap Pluralitas Budaya.

5. Kajian Penelitian yang Relevan

Hasil penelitian Imam Aji Subagyo (2012), “ Pengaruh Keterlaksanaan Nilainilai Multikultural terhadap Sikap Pluralis Siswa SD se-Kecamatan Umbulharjo”.

a. Persamaan

Persamaan antara penelitian yang dilakukan oleh Imam Aji Subagyo dengan penelitian ini adalah terletak pada pembahasanpembentukan karakter dan sikap pluralis siswa.

b. Perbedaan

Perbedaannya yaitu jika penelitian yang dilakukan oleh Imam Aji Subagyo itu meneliti dari keterlaksanaannya nilai-nilai multikultural sedangkan penelitian 
yang saya lakukan adalah meneliti sejauh mana peran pendidikan Ilmu Pengetahuan Sosial tersebut dalam pembentukan karakter pluralis siswa.

\section{METODOLOGI}

1. Jenis Penelitian

Penelitian ini merupakan penelitian dengan menggunakan jenis penelitian kualitatif. Pada penelitian kualitatif peneliti memasuki situasi sosial tertentu yang dapat berupa lembaga pendidikan tertentu, melakukan observasi dan wawancara kepada orang-orang yang dipandang mengetahui situasi sosial tersebut, penentuan sumber data pada orang yang diwawancarai dilakukan secara purposive, yaitu dipilih dengan pertimbangan dan tujuan tertentu.Sedangkan metode yang digunakan metode deskriptif. Metode deskriptif adalah metode penelitian yang berusaha menggambarkan dan menginterpretasi objek sesuatu dengan apa adanya, dari data teoritik dan data hasil ke lapangan. Jenis penelitian kualitatif sebagai prosedur penelitian yang menghasilkan data deskriptif berupa kata-kata tertulis dari orang-orang dan perilaku yang diamati (Moleong, 2004:4).

\section{Lokasi dan Waktu Penelitian}

Penelitian dilakukan di MTs Negeri 11 Cirebon. Adapun waktu pelaksanaan penelitian dari bulan Desember 2017 - Februari 2018.

3. Sumber Data

Sumber data yang didapat dari sebagai berikut :

a. Sumber data primer, yaitu data yang diperoleh secara langsung dari objek yang diteliti. Data ini dapat berupa hasil teks wawancara dan diperoleh melalui wawancara dengan informan yang sedang dijadikan sampel dalam penelitiannya (Suwarno, 2006:209).

b. Data primer dalam penelitian ini adalah data - data yang diperoleh dari kepala sekolah, guru mata pelajaran IPS, Kepala Sekolah, Guru BK, dan Siswa-Siswi MTs N 11 Cirebon.Sumber data sekunder, yaitu data tambahan berupa informasi yang akan melengkapi data primer. Data sekunder yang peneliti peroleh dari penelitian yang telah dilakukan antara lain:

1) Dokumen atau arsip dari sekolah MTs N 11 Cirebon. 
2) Data sekunder lain yaitu dokumentasi berupa foto-foto yang peneliti hasilkan sendiri dengan kamera digital, catatan hasil wawancara yang diperoleh peneliti saat melakukan wawancara dengan subjek dan informan penelitian serta data-data lain yang dijadikan bahan tambahan untuk mendapatkan data objek penelitian.

4. Subyek Penelitian

Subyek penelitian terfokus pada mata pelajaran IPS, guru mata pelajaran IPS, dan siswa-siswi kelas VIII yang terlibat dalam proses pembelajaran IPS.

5. Teknik dan Instrumen Pengumpulan Data

a. Wawancara

Responden atau informandalam wawancara ini adalah sesuai pilihan sekolah yaitu Guru IPS, Kepala Sekolah, Guru BK, dan Siswa. Guna menghindari pokok pembahasan yang panjang lebar, maka dibuatlah pedoman wawancara untuk masing-masing responden.

b. Observasi

Observasi yang dilakukan dalam hal ini, peneliti berkedudukan sebagai non-participant observer, yakni peneliti tidak turut aktif setiap hari berada di sekolah tersebut, hanya pada waktu penelitian.

c. Dokumentasi

Metode dokumentasi ini dimaksudkan untuk memperoleh data berdasarkan sumber data yang ada di sekolah.

d. Triangulasi

Dalam teknik pengumpulan data, triangulasi diartikan sebagai teknik pengumpulan data yang bersifat menggabungkan dari berbagai teknik pengumpulan data dan sumber data yang telah ada

6. Teknik Analisis Data

a. Pengumpulan data

Peneliti mencatat semua data secara objektif dan apa adanya sesuai dengan hasil observasi dan wawancara di lapangan.

b. Reduksi Data

Mereduksi data berarti merangkum, memilih hal-hal yang pokok, memfokuskan pada hal-hal yang penting dicari tema dan polanya dan membuang yang tidak perlu. 
c. Display Data / Penyajian Data

Penyajian data berbentuk sekumpulan informasi yang tersusun sehingga dapat ditarik suatu kesimpulan. Penyajian data dilaksanakan agar sajian data tidak menyimpang dari pokok permasalahan.

d. Penarikan kesimpulan

Penarikan kesimpulan atau verifikasi adalah usaha untuk mencari atau memahami makna, keteraturan, pola-pola, penjelasan, alur sebab akibat atau proposisi. Verifikasi penulis lakukan setelah penyajian data selesai, dan ditarik kesimpulanya berdasarkan hasil penelitian lapangan yang telah dianalisis dengan teori.

\section{Keabsahan Data}

Sugiono (2016: 331) menyatakan bahwa "uji keabsahan data dalam penelitian, sering hanya ditekan pada uji validitas dan reabilitas. Dalam penelitian kualitatif, kriteria utama terhadap data hasil penelitian adalah, valid, realibel, dan obyektif.”

\section{HASI PENELITIAN DAN PEMBAHASAN}

Berdasarkan hasil data-data dari hasil wawancara dan penelitian yang peneliti lakukan mengenai proses pembelajaran IPS IPS di MTs N 11 Cirebon semua Guru IPS sepakat mengatakan bahwa sudah maksimal. Sebelum pelaksanaan pembelajaran IPS, guru-guru mata pelajaran IPS membuat RPP (Rancangan Pelaksanaan Pembelajaran), mempersiapkan bahan ajar, dan menyantumkan nilai yang akan ditanamkan dalam pembelajaran IPS tersebut. Dengan ini membuktikan bahwa proses pembelajaran IPS di sekolah tersebut sudah melakukan perencanaan yang baik, dari perencanaan yang baik akan mencerminkan pelaksanaan yang baik pula.

Peran pendidikan IPS dalam memebentuk karakter pluralis siswa, Berdasarkan hasil data-data dari hasil wawancara dan penelitian yang peneliti lakukan mengenai proses pembelajaran IPS IPS di MTs N 11 Cirebon semua Guru IPS sepakat mengatakan bahwa sudah maksimal.

Sebelum pelaksanaan pembelajaran IPS, guru-guru mata pelajaran IPS membuat RPP (Rancangan Pelaksanaan Pembelajaran), mempersiapkan bahan 
ajar, dan menyantumkan nilai yang akan ditanamkan dalam pembelajaran IPS tersebut. Dengan ini membuktikan bahwa proses pembelajaran IPS di sekolah tersebut sudah melakukan perencanaan yang baik, dari perencanaan yang baik akan mencerminkan pelaksanaan yang baik pula.

Kurikulum yang digunakannya menggunakan Kurtilas yang sudah direvisi pada tahun 2016 yang sekarang kita sering sebut Kurnas (Kurikulum Nasional). Dalam mendesain kurikulum pendidikan IPS, termasuk dalam proses pembelajarannya, harus juga berangkat dari hakikat dan karakter peserta didik, bukan berorientasi pada materi semata. Pendekatan esensialisme sudah saatnya untuk dimodifikasi dengan teori rekonstruksi sosial yang mengacu pada teori pendidikan interaksional (Dian, wawancara 10 Januari 2018).

Pembelajaran IPS mempelajari keadaan masyarakat yang cepat perkembangannya. Pengembangan kurikulum IPS merupakan jawaban terhadap tuntutan kebutuhan masyarakat yang akan mempelajarinya. Perkembangan IPS dilatarbelakangi oleh beberapa hal diantaranya :

a. Pengalaman hidup masa lampau dengan situasi sosialnya yang labil memerlukan masa depan yang lebih mantap dan utuh sebagai suatu bangsa yang bulat.

b. Laju perkembangan pendidikan, teknologi, dan budaya Indonesia memerlukan kebijakan pendidikan pengajaran yang seirama dengan laju perkembangan tersebut.

c. Agar output pendidikan persekolahan benar-benar lebih relevan dengan tuntutan masyarakat yang ia akan menjadi bagiannya dan materi yang dimuat dalm kurikulum atau dipelajari peserta didik dapat bermanfaat.

Kajian yanag dipelajari dalam Ilmu Pengetahuan Sosial, sebagai berikut :

a. Sosiologi mempelajari segala hal yang berhubungan dengan aspek hubungan sosial yang meliputi proses, faktor, perkembangan, permasalahan, dan lain-lain.

b. Ekonomi mempelajari proses, perkembangan, dan permasalahan yang berhubungan dengan ekonomi.

c. Aspek sejarah yang tidak dapat dipisahkan dalam kehidupan kita dipelajari dalam sejarah. 
d. Aspek geografi yang memberi efek ruang terhadap kehidupan manusia dipelajari dalam geografi.

Karakter pluralis siswa dengan adanya pendidikan IPS di MTs N 11 Cirebon mudah bergaul, berteman dengan siapa saja tanpa melihat status temannya. Jika dilihat siswa menyikapi perbedaan dengan teman-temannya itu masih samar-samar karena jika di Sekolah siswa-siswi memakai seragam yang sama dan diperlakukan sama. Misalnya anak orang kaya memakai sepatu boleh warna-warni, yang seperti itu tidak ada yang perlakuan seperti itu.

Dari letak geografis sekolah juga memang terletak diantara masyarakat yang berbahasa Sunda dan Jawa, dan pastinya banyak perbedaan dari tiap-tiap siswa disekolah ini, namun yang peneliti amati bahwa siswa-siswi di sekolah ini menyikapi perbedaan dengan baik, bahkan tak sedikit siswa yang berasal dari daerah Jawa bersahabat dengan siswa yang berasal dari daerah Sunda. Siswasiswinya pun saling menghargai dan saling menolong antar sesama teman yang membutuhkan. Indikator siswa yang berkarakter pluralis biasanya siswa mencerminkan sikapnya yang mudah bergaul dan memiliki banyak teman, dari banyaknya teman itu pasti siswa memiliki sikap yang baik hingga bisa diterima oleh teman-temannya.

Disamping itu juga kita bisa menilai karakter siswa dilihat dari shalatnya, karena sekolah kita menganjurkan sholat berjama`ah di masji setap waku dzuhur, dan terjadwal juga sholat dhuha. Terkadang ada siswa yang sholat dhuha sendiri tanpa disuruh. Dan ketika dilihat siswa tersebut memiliki sifat dan kelakuannya baik pula. Tak lepas tugas sekolah selain untuk mencerdaskan siswasiswi nya sekolah juga memiliki tugas untuk mencetak siswa-siswi yang berkarakter, yang berbudi pekerti luhur, yang beretika, dan bersosial di masyarakat.

Pembelajaran IPS memiliki peran penting dalam pembentukan karakter bangsa. Sebab pembelajaran IPS memiliki kesamaan dengan pendidikan nilai atau pendidikan karakter yang masing-masing bertujuan untuk menjadikan peserta didik sebagai warga negara yang baik, kemudian juga peduli terhadap masalah sosial dan lingkungannya, serta memiliki rasa kebangsaan yang tinggi. 
Dengan mencermati uraian tentang pengertian dan tujuan IPS, akan terlihat bahwa pendidikan IPS sebenarnya sangat erat kaitannya dengan pendidikan karakter atau sikap. Hal ini terlihat pada rumusan tujuannya, bahwa pendidikan karakter atau pendidikan nilai (sikap) juga bertujuan agar peserta didik menjadi warga negara yang baik.

Para peserta didik begitu tertarik dengan mata pelajaran IPS. Dengan demikian dapat dipastikan bahwa pembelajaran IPS menjadi optimal, sehingga tujuan pembelajaran IPS yang sesungguhnya sebagai bagian dari proses pembentukan karakter dapat tercapai. Karena sekolah tersebut melakukan berbagai upaya. Diantaranya sekolah melakukan telaah kurikulum, yang semula pengembangannya berbasis materi, diubah berbasis kompetensi dan karakter. Serta mengembangkan proses pembelajaran yang aktif, partisipatif dan kontekstual.

Untuk memantapkan peran pendidikan IPS dalam membentuk karakter pluralis siswa di MTs N 11 Cirebon ini perlu juga didukung dengan beberapa hal, sebagai berikut; Perlu adanya keteladanan, proses pembelajaran dikembalikan kepada tujuan dasarnya sebagai proses pendidikan, dikembangkan modelmodel pembelajaran yang aktif - partisipatif, kreatif- inovatif dengan berbagai program pembiasaan, penciptaan lingkungan pendidikan yang kondusif-edukatif, misalnya dipajang berbagai ketentuan, prosedur, slogan-slogan yang mampu memberikan motivasi dan semangat dalam hidup dan kehidupan yang lebih berkarakter, perlu penataan berita dan penyiaran di berbagai media massa, baik di media cetak maupun elektronik, perlu dilakukan kerja sama dengan orang tua/wali dan masyarakat sekitar, adanya political will dari pemerintah.

Faktor yang mempengaruhi dalam membentuk karakter pluralis berdasarkan desripsi data menunjukan bahwa ada berbagai faktor pendukung dan penghambat dalam membentuk karaker pluralis siswa di MTs N 11 Cirebon. Faktor pendukung meliputi: letak geografis daerah yang berbeda budaya saling berdekatan, adat yang memiliki tabiat yang sama untuk membentuk karakter pluralis siswa, budaya yang hampir sama atau banyak kemiripan, membaurnya pertemanan siswa, siswa memiliki sifat terbuka, siswa saling mengingatkan untuk saling menghargai, saling membantu, dan gotong royong sesama teman, dan peran 
orang tua dan lingkungan serta sistem pendidikan yang bersinergi untuk membentuk karakter pluralis siswa. Sedangkan faktor penghambat meliputi: letak geografis daerah yang berbeda budaya berjauhan, adat yang memiliki tabiat yang berbeda sehingga untuk membentuk karakter pluralis siswa sulit, budaya yang berbeda kebiasaanya, tidak membaurnya pertemanan siswa, siswa memiliki sifat tertutup, siswa tidak saling mengingatkan untuk saling menghargai, saling membantu, dan gotong royong sesama teman, dan peran orang tua dan lingkungan serta sistem pendidikan yang tidak bersinergi untuk membentuk karakter pluralis siswa.

\section{E. KESIMPULAN DAN SARAN}

1. Kesimpulan

Berdasarkan hasil penelitian yang peneliti lakukan, maka dapat disimpulkan data dan uraian sebagai berikut :

a. Berdasarkan hasil data-data dari hasil wawancara dan penelitian yang peneliti lakukan mengenai proses pembelajaran IPS IPS di MTs N 11 Cirebon semua Guru IPS sepakat mengatakan bahwa sudah maksimal.

b. Karakter pluralis siswa dengan adanya pendidikan IPS di MTs N 11 Cirebon mudah bergaul, berteman dengan siapa saja tanpa melihat status temannya. Jika dilihat siswa menyikapi perbedaan dengan teman- temannya itu masih samar-samar karena jika di Sekolah siswa-siswi memakai seragam yang sama dan diperlakukan sama.

c. Faktor yang mempengaruhi dalam membentuk karakter pluralis berdasarkan desripsi data menunjukan bahwa ada berbagai faktor pendukung dan penghambat dalam membentuk karaker pluralis siswa di MTs N 11 Cirebon.

2. Saran

a. Bagi Guru. Guru hendaknya melihat seluruh faktor yang terlibat dalam pembentukan sikap pluralis saling mendukung dan tidak saling bertolak belakang, sehingga sikap pluralis yang diharapkan dapat terwujud secara utuh. 
b. Bagi siswa. Siswa hendaknya mampu berperan aktif dengan menyampaikan gagasan atau pemikiran pada proses pembelajaran sehingga belajra mengajar yang didapatkan nantinya kan berhasil optimal.

\section{DAFTAR PUSTAKA}

Azwar, Saefudin. 1997. Sikap Manusia, Teori dan Pengukurannya. Yogyakarta: Pustaka Pelajar.

Bagir, Zainal Abidin dkk. 2011. Pluralisme Kewargaan. Bandung: Mizan.

Baidhawy, Zakiyuddin. 2007. "Pendidikan Agama Berwawasan Multikultural”. Jakarta: Erlangga.

Kuntowijoyo. 2017. Paradigma Islam Interpretasi untuk Aksi. Yogyakarta: Tiara Wicana.

Kesuma, Dharma dkk. 2012. Pendidikan Karakter. Bandung: Remaja Rosdakarya.

Megawangi, Ratna. 2004. Pendidikan Karakter Solusi Yang Tepat Untuk Membangun Bangsa. Jakarta: BPMGAS.

Moeljono Cokrodikardjo. 1980. Pendidikan IPS. Yogyakarta: Pustaka Pelajar.

Moleong, J. 2004. Metodologi Penelitian Kualitatif. Bandung: Remaja Rosda Karya.

Nadir, dkk. 2009. Pendidikan Ilmu Penegtahuan Sosial. Jakarta : Rineka Cipta.

Soemantri, Muhammad Numan. 1998. Pendidikan IPS. Bandung: Rosda Karya.

Suwarno, Jonathan. 2006. Metode Penelitian Kualitatif Dan Kuantitatif. Yogyakarta: Graha Ilmu.

Sugiono. 2016. Metode Penelitian Pendidikan Pendekatan Kuantitatif, Kualitatif, dan R\&D. Bandung: Alfabeta.

Zubaedi. 2011. Desain Pendidikan Karakter. Jakarta: Kencana Prenada Media Group.

http://referensi.elsam.or.id/2014/11/uu-nomor-20-tahun-2003-tentang sistempendidikan-nasional/ diakses pada tanggal 02 Januari 2018 pukul 10.20 WIB. 